\title{
University
}

Fraser, A., Ralphs, R. and Smithson, H. (2018) European youth gang policy in comparative context. Children and Society, 32(2), pp. 156-165.

There may be differences between this version and the published version. You are advised to consult the publisher's version if you wish to cite from it.

This is the peer reviewed version of the following article:

Fraser, A., Ralphs, R. and Smithson, H. (2018) European youth gang policy in comparative context. Children and Society, 32(2), pp. 156-165, which has been published in final form at http://dx.doi.org/10.1111/chso.12265

This article may be used for non-commercial purposes in accordance with Wiley Terms and Conditions for Self-Archiving.

http://eprints.gla.ac.uk/155725/

Deposited on: 13 February 2018

Enlighten - Research publications by members of the University of Glasgow http://eprints.gla.ac.uk 


\section{Gang policy in comparative context}

In recent years, processes of economic globalisation have resulted in widening urban inequalities around the world, accelerating the conditions in which territorial, street-based criminal organisations - often referred to as 'gangs' - frequently emerge. Indeed, the past decade has seen increased reports of street gangs across several continents spanning Africa, Asia, Australia and Europe, with the American street gang often acting as archetype (van Gemert et al 2008, Esbensen and Maxson 2012, Decker and Pyrooz, 2015). Tracing a similar trajectory, policy responses to gangs have become increasingly prominent across a number of European jurisdictions, most notably in the UK. Mirroring a broader pattern of policy mobility, many of these new forms of intervention have US origins. It remains unclear, however, the extent to which these convergences result from an evidenced response to a clearly articulated social problem, or as a result of forms of policy transfer against gangs as 'useful enemies' (Cornils and Grieve 2004). In this review, we examine gang policy in Europe, drawing particular attention to the UK, as a means of interrogating the transferability of gang policies. In sum, we argue for the need to exercise caution over adopting US gang intervention tactics due to the lack of empirical evidence relating to their applicability or efficacy, and the corresponding potential for discrimination toward the most marginalised and socially excluded children and young people in society.

\section{Gangs, punitivism and policy mobility}

Before focusing attention to European and UK policy, a brief note on the United States policy context is necessary, as the stimulus for criminal justice developments elsewhere. Unlike Europe, the study of youth 'gangs' in the United States - identifiable groups of streetbased youth, involved in illegal activities, with a distinct identity - has a long and rich history. Stretching back nearly a century and encompassing several canonical works in the study of youth, the study of gangs has developed into a mature sub-field of criminology and criminal justice. From ethnographic studies (Thrasher 1927; Campbell 1984; SanchezJankowski 1991) to large scale, nationally representative surveys (National Youth Gang Survey, 1996 - 2012), policy-makers can draw on an evidence base, albeit a partial one, and there is a degree of consensus that the term 'gang' refers to a phenomenon with some 
grounding in reality. Against this backdrop, a large and varied array of criminal justice interventions have developed, with tactics focusing on three approaches: prevention, intervention, and suppression (Bjerregaard, 2003). While prevention and intervention through social outreach and street work were popular for a time, in the context of rising fear of crime, increases in gang violence, and a perception that social interventions were ineffective (Braga, 2015), gang policing based around the suppression model became increasingly dominant in the 1960s (Chaskin, 2010). This involved an expansion of specialist units focusing on gangs and gun violence, and successively the use of 'street sweeps', stopand-search, and 'zero-tolerance' models of policing, with the use of intelligence databases and multi-agency working increasingly prevalent. The research evidence for the efficacy of these suppression tactics are, however, modest at best (see Klein, 1995; Spergel, 1995; Maxson and Klein, 2006).

In Europe, conversely, youth gangs by and large represent a 'newly noticed kind of human behaviour' (Hacking 1999: 136) that has yet to be established as an empirically identifiable phenomenon. Though comparative work has developed significantly over the last two decades - primarily through the aegis of the Eurogang Network - there remains significant debate as to the applicability of the 'gang' categorisation to European streetbased youth (Klein et al 2001; Decker and Weerman 2005; Esbensen and Maxson 2012). While a common definition has been agreed among academic researchers ('any durable, street-oriented youth group whose involvement in illegal activity is part of their group identity'; van Gemert 2005: 148), there have been challenges associated with deploying this definition across different jurisdictions. In a review of the programme, Klein (2011) points to difficulties with language, misinterpretation, and translation in attempting comparative research of this kind. Critics of the Eurogang approach note further that the term 'gang' does not always easily map onto these groups, and local differences are missed by a single definition (Aldridge et al 2008). As research has demonstrated, moreover, there are wide variations in the meaning and application of the term 'gang' both within jurisdictions such as the UK (Fraser 2015), between the US and UK (Hallsworth and Brotherton 2011; Fraser and Hagedorn 2016), and among criminal justice practitioners across these differing jurisdictions. The picture is still emerging and clearly lacking several pieces of the jigsaw (Ralphs and Smithson, 2015; Smithson and Ralphs, 2016). 
Despite this lack of clear evidence-base, however, it is clear that US-influenced gang policies have begun to take root across a number of European contexts, notably the use of civil gang injunctions, police gang units, intelligence databases and multi-agency working practices. In some cases, these strategies have been demonstrated to result in 'netwidening' processes, in which young people not associated with gangs become negatively impacted. It is worth noting that these forms of policy mobility take place against a backdrop of increased punitivism toward youth crime in a range of contexts. As Muncie (2007) notes, there has been a notable trend toward punitivist policy shifting from the US toward Europe, for example the use of curfews, mandatory sentencing and electronic monitoring (Muncie, 2007: 26), involving both policy convergence and transfer (Goldson 2014). These shifts echo broader changes in criminal justice in which 'a new civil and political order structured around the problem of violent crime' has gathered pace (Simon, 2007: 3). These shifts are marked by clearly racialised and class-based forms of inequality, with poor, minority ethnic and migrant communities significantly over-represented in rates of imprisonment and criminal justice intervention (Wacquant 2008).

In what follows, we review a range of gang policy developments in Europe, with a particular focus on the UK, drawing attention to the way in which gang policies appear to follow this broader pattern. We suggest that a 'one-size-fits-all' approach to this complex and differentiated phenomenon can have serious implications for some of the most vulnerable and marginalised children and young people.

\section{Gang policy in Europe}

The landscape of gangs across Europe presents a confusing picture, with substantial variability in the meaning of the term 'gang', the process of collecting administrative statistics, and the way in which young people are categorised. In the Netherlands, for example, national figures published in 2010 report 1,154 'youth groups', with only six of these defined as 'jeugdbendes' (or 'gang' equivalent). In Spain, there are reportedly three different types of gangs, the extreme right, extreme left, and Latin "bands" (i.e., groups) (Pozo et al. 2013). French figures illustrate a rise in numbers from 2009 to 2011, with 222 gangs involving 2500 individuals in 2009, increasing to 313 gangs in 2011 (Cervantes and Marchand 2013). In other countries, such as Italy and Portugal, figures relating to gangs and 
gang membership simply do not exist. Alongside clear issues with divergent meanings and contexts, these variations of measurement and meaning make it virtually impossible to measure the extent of gangs across Europe. Whether or not they are labelled as 'gangs', however, it is clear that there are street-based groups of young people forming into groups in response to economic, racialised and social exclusion across a range of jurisdictions (van Gemert et al 2008).

Despite this 'patchy, variable and unreliable' (Ralphs and Smithson, 2015: 525) knowledge-base, there have been notable recent efforts to collectivise Europe-wide responses to 'gangs' through the 'Interaction of different subjects Towards A strategic Common Answer concerning juvenile gangs' (ITACA) research portfolio. The project was funded by the European Union's Daphne II programme and set out to implement a European multi-level analysis of 'juvenile gangs'. Research including empirical data collection and literature based evidence was conducted with partner institutions across six European countries - Belgium, France, Italy, Portugal, Spain, and the United Kingdom between March 2011 and February 2013 (ITACA 2013). The project recognised that there is not a commonly accepted definition of 'juvenile gangs' or even of what constitutes 'juvenile delinquency' within the EU' (ITACA, 2013:12). Therefore, it sought to examine different definitions and contexts. The research revealed that European gang policy is developing at different rates, with considerable variations as to the nature, meaning and translation of the term 'gang' - from gjeng in Norway to bande in France and jeugdbendes in the Netherlands (Ralphs and Smithson, 2015: 522). Though some countries have a working policy definition of gangs, these may refer to quite distinct groups within that context, for example 'biker' gangs in Denmark or Latino social movements in Spain (Brotherton 2007). Further, there are several countries - for example Sweden, Italy, France and Portugal - who have no definition at all. Despite efforts toward harmonisation, it is important to note that policy-making is guided by the deeper penal philosophies of different justice systems - with some countries more socially oriented, while others tend more towards criminal justice responses (Rostami, 2016). Nonetheless, it is apparent that certain patterns are emerging across a number of jurisdictions.

At a European level, it is clear that gang policing units, multi-agency approaches, and policing intelligence databases represent a common thread in policy responses to youth gangs, albeit with specific articulations according to national context. For example, in Spain, 
2005, the Ministry of Interior through the Secretary of State, established the 'Police coordination and intervention plan against organized violent juvenile groups'. It was renewed in 2008 and replaced in 2009 by the new Instruction of the State Secretary of Security, to boost and continue the aforementioned plan (Pozo et al. 2013). The objective of the plan is to coordinate preventive and operational police force activities, including: increasing intelligence on gangs through mapping and monitoring; cross-agency training on gang issues; increasing contact with teachers, parents and young people; setting up of government advisory groups and improving collaboration within criminal justice settings including prisons (Pozo et al., 2013). In France, in March 2010, a circular set out action plans to implement local strategies to address gangs. The objectives were three-fold dependent on the type of gang: (1) Preventing crime and violence, (2) The prevention the use of public spaces for the instigation of riots and inter-gang clashes and (3) Prevention of organized trafficking. These objectives are to be met by the 'gang shut down' strategy, which relies on increasing the intelligence within areas exposed to the above problems by making use of real time intervention; strengthening legal responses by adapting local units; increased prevention and partnerships through youth awareness, jointly working with the Youth Judicial Protection Service; developing Local Security and Crime Prevention Committees and partnership working with the national education system (see Cervantes and Marchand, 2013).

Elsewhere, however, rather than police and multi-agency approaches, legislative or health-based approaches have been more pronounced. In Italy, for example, the ITACA project reported that anti-gang legislation was still in its early stages but nevertheless, was described to be 'extremely promising' (Padovani et al., 2013). In Portugal, although the phenomenon of juvenile gangs has no official definition or data, the professionals who deal with juvenile delinquency consider it a significant issue. According to these groups, there are many problems in the Portuguese intervention policies concerning juvenile gangs. The few implemented actions towards juvenile delinquency in gangs are generally considered ineffective and uncoordinated. Nevertheless, some intervention practices are named as good examples. Working with youngsters and their families in the community, for example in socially deprived areas where youngsters are at higher risk of becoming involved in violent offending and participating in gangs, is seen as a positive practice. The "Programa Escolhas" is named by $23 \%$ of the practitioners as the most important programme carried 
out in Portugal with impact on the prevention and intervention in juvenile delinquency (Padovani et al., 2013). Implemented in 2001, it includes several small projects undertaken in "risk" areas throughout the country, and continuously over time. It aims to prevent a wide range of social problems in specific territories, and is carried out by multidisciplinary teams involving the communities (Matos et al., 2013).

The Scandinavian countries offer an interesting perspective on gang policy. They are different to other European counterparts as it is recognised that two different types of gangs exist - biker gangs and more recently organised street gangs. According to Carlsson and Decker (2005:18), Scandinavian gang policy reflects these differences, 'the Scandinavian intervention diet represents a mixture of both suppression and social-intervention strategies'. Denmark and Norway both have dedicated police gang units, while welfare oriented interventions can be found in the Stockholm Gang Intervention and Prevention Programme (SGIP), which incorporates the operational PANTHER Gang Model both of which are based on holistic approaches including suppression, intervention, and prevention (Leinfelt and Rostami, 2012).

The knowledge and subsequent evidence base of the youth gang situation in Europe is inconsistent at best. We see that gang policy is clearly permeating legislation and practice but at varying rates and through varying responses. We alluded earlier to the significance of the deeper penal philosophies of the justice systems in question (Rostami, 2016). Reading across these trends, Ralphs and Smithson draw attention to the status of gangs as a lightning rod for broader social anxieties (Ralphs and Smithson, 2015: 530) during moments of uncertainty, resulting in intensified securitisation and efforts at moral regulation, what Cornils and Greve (2004) refer to as "useful enemies". There is no better example of this than the UK, which we argue is the most advanced region of Europe in terms of youth gang policy and practice, where a raft of criminal justice focused responses to gangs has developed. It is to these responses that we now turn our attention.

Gang policy in the UK

In the UK, there has been a gathering academic and policy focus on youth gangs in recent years (Goldson 2011). Despite this increase in attention, however, there remains a great deal of debate and contest as to the nature of youth gang affiliation in the UK, and the 
extent to which apparent changes in youth culture represent activity that is appropriately labelled as 'gang-related', or whether this simply represents a new way of categorising and policing an unchanged youth culture (Fraser 2017). For some academics, gangs represent a discernible threat that require targeted criminal justice responses (Pitts, 2008, Harding 2012 , 2014). For many others, however, the evidence-base is weak and holds potential for significant discrimination; with 'gang talk' frequently coded with racialised, gendered and class-based stereotypes (Alexander 2008, Pitts 2008, Medina et al 2012; Smithson et al 2013, Hallsworth 2014, Williams and Clarke 2016). Notably, the government's previous reluctance to use the term 'gangs' in favour of terms such as troublesome youth groups (Bannister et al 2010), and 'delinquent youth groups' (Sharp et al 2006, Young et al 2007) has increasingly become replaced with a clearer focus on 'gangs'. The UK's definition was developed in 2009 by the Gangs Working Group and was referred to in EGYV report (HM Government, 2011), as follows:

\begin{abstract}
A relatively durable, predominately street-based group of young people who (1) see themselves (and are seen by others) as a discernible group, (2) engage in a range of criminal activity and violence, (3) identify with or lay claim over territory, (4) have some form of identifying structural feature and (5) are in conflict with other, similar gangs (Centre for Social Justice, 2009, p. 21).
\end{abstract}

The emergence of gangs as an object of public policy in the UK dates back to 2007, in the form of the Tackling Gangs Action Plan (TGAP) in four of England's largest cities: London, Manchester, Birmingham and Liverpool. Each TGAP city now includes both 'US-style' dedicated gang/firearm units within their police forces and Boston Ceasefire influenced multi-agency responses to the 'gang problem' (e.g. 'MAGU' (Multi-Agency Gang Unit) in Birmingham and 'IGMU' (Integrated Gang Management Unit) in Manchester). Many cities now have local authority Violent Gang Boards and legislation was passed to introduce gang injunctions in the 2009 Policing and Crime Act, also with origins in the US. It was in aftermath of the English riots, however, that the policy focus - and policy mobility increased markedly. In the days following the riots, then Prime Minister David Cameron was unequivocal in apportioning blame. Despite a questionable evidence base (Smithson and Ralphs, 2016), 'stamping out gangs' declared as a 'national priority'. Within months, the UK's first national gang strategy, 'Ending Gangs and Youth Violence' (EGYV); Home Office 2011), was introduced, marking a significant shift in government rhetoric relating to gangs. 
It is notable, however, that many of these policy initiatives were implemented without a clear evidence-base. As Alexander notes, "the gang" has developed a public life independent of any empirical foundation or conceptual exploration - full of its own sound and fury, but signifying very little' (Alexander 2008: 3). In this context, Hallsworth and Brotherton (2011) issued a 'critique and warning' of the transference of US gang policy to the UK in the aftermath of the English riots of 2011.

While EGYV was seen as a success by some (House of Commons, 2015), a number of critiques have emerged that question the rationale and consequences of these new policies (Shute et al., 2012). Critics point to the lack of evidence of efficacy of new measures, the potentially negative consequences involved in labelling young people as gang-involved, and the ways in which it misinterprets complex issues of youth violence. Shute and Medina (2014: 1), for example, argue that EGYV is 'untheorised, unevidenced, and unevaluated' and 'risks reifying the very problem it claims to fear'. A Home Affairs Committee concluded in 2015 that despite significant investment, the Home Office 'has failed to effectively evaluate the project', pointing to the need to undertake high-quality comparative evaluation in order to assess what works best in combating gang and youth crime and in identifying areas for improvement' (House of Commons Home Affairs Committee Report, 2015: 8). This lack of evidence-base has, moreover, been demonstrated to result in forms of discrimination and bias. For Cottrell-Boyce (2013), policies are based on contradictory evidence and result in a 'net-widening' effect: a 'drag-net approach which criminalizes innocent young people rather than focusing resources on serious violent crime' (Cottrell-Boyce, 2013: 193). According to Klein and Maxson (2006: 221), 'ethnicity is one of the most widely discussed, and little studied, aspects of gangs'. As Williams and Clarke (2016) found in a study of the consequences of EGYV, local authority areas that were able to demonstrate a 'gang problem' were more likely to attract funding, with black and minority ethnic communities more likely to be perceived as 'gang areas' (Williams and Clarke, 2016: 4). Summarising these trends, Ralphs and Smithson note that the UK has begun a 'perilous path of drifting into US-style interventions, despite the largely unproven (or at best merely promising) evidence of intervention success in the United States' (Ralphs and Smithson, 2015: 533).

An example of the discriminatory impact of these policies can be found in the use of gang intelligence databases in the UK. This is a centralised dataset containing a range of police intelligence involving individuals with a 'marker' for gangs, which may be added to 
their 'associations' with 'known' gang-members (Fraser and Atkinson 2014). As Spergel notes, however, databases 'raise strong questions about validity, reliability, as well as public-policy utility of gang law-enforcement definitions and gang databases' (Spergel 2009: 667). While some US states have more stringent criteria - one model distinguishes between 'suspected', 'confirmed' and 'confirmed and convicted' gang members (Spergel 2009) critics argue that there are inherent difficulties in attributing these labels (Jacobs 2009). Fraser and Atkinson (2014) argue that gang-membership is increasingly attributed through systems of police intelligence on the basis of incomplete information, and analysed by civilian officers with little contextual knowledge of the meanings of these terms. In an analysis of a UK gang database, Clarke et al (2012) similarly found significant inaccuracies. While $58 \%$ could reasonably be said to be 'gang-involved', the list also included those associated with gangs, those who used to be in a gang, and those 'at risk' of gang violence. Importantly, these labels can have a significant impact on young people's lives, ranging from 'undeserved law-enforcement attention', 'statutory sentencing enhancements' in the US (Kennedy 2009: 711) to 'greater vulnerability to police attention and surveillance' and 'police raids on family homes' (Ralphs et al 2009: 491).

One striking finding in relation to the use of gang databases, in both the US and UK, is the potential for discrimination. In a study in London, $87 \%$ of 'nominals' on the Metropolitan police database were Black, Asian or minority ethnic (Williams and Clarke 2016). This raises critical questions as to the ways in which new techniques and technologies of policing perpetuate prejudice and implicit bias. As Alexander has noted, gangs have historically been used as a scapegoat for broader social anxieties, often in a heavily racialised way (Alexander 2008). More recently, Smithson et al have noted the ways in which gang intelligence and accompanying policy frameworks including 'gang injunctions and dedicated multi-agency and policing units disproportionately target young, ethnic minority males from already socially excluded, marginalized and heavily policed neighbourhoods' (Smithson et al 2013: 125). Despite the 30-year history of US gang injunctions, there is very little research evaluating their effectiveness; what does exist shows highly variable effects on community crime levels and on fear of crime (see Maxson et al. 2005). This questionable evidence of effectiveness sits alongside criticism on a number of fronts, including as racially discriminatory or as infringing on the right to freedom of movement (see Stewart 1998). While there is clearly racialisation of gangs in the UK, we 
concur with Smithson et al, who assert that 'very few academic or empirical gang studies have sought to acknowledge or understand the 'unmentionable' nexus between ethnicity and gangs' (2013: 4).

Most recently, UK gang policy debates - traditionally dominated by a focus on male gang members - have increasingly placed emphasis on the relationship between gangs and child sexual exploitation (CSE) (see EGYV 2011, Berelowitz et al 2012, Latchford et al 2016). To date, however, it remains unclear to what extent this represents a well-evidenced link or an instance - as above - of policy-making outrunning the available evidence. On one hand, the 2013 report from the Office of the Children's Commissioner - 'If only someone had listened', makes a clear link between CSE and gangs and groups and the work of Jenny Pearce and colleagues ('It's wrong but you get used to it', commissioned by the Office of the Children's Commissioner, 2013) has been hugely influential in ensuring that CSE receives the high profile political and policy focus it deserves. These reports highlight the highly racialised discourse around CSE in the UK. The vast majority of convicted child-sex offenders in the UK are single White men ('If only someone had listened', Office of the Children's Commissioner, 2013) which is in stark contrast to the way in which these offences tend to be publicised by mainstream media. On the other, however, despite no discernible link between CSE and the English riots, a central tenet of the EGYV strategy included the pledge to invest "at least $f 1.2 \mathrm{~m}$ of additional resource over the next three years in improving services for young people under 18 suffering sexual violence in our major urban areas - with a new focus on the girls and young women caught up in gang related rape and abuse" (EGYV 2011:7).

\section{Conclusion}

This review has noted a growing trend for gang policy mobility from the US to Europe, particularly the UK, with a particular focus on specialised policing units, multi-agency approaches, gang intelligence databases and legislation. Reflecting broader trends toward punitivism in youth justice (Goldson 2014), we have highlighted how the discourse of gangs is penetrating youth justice policy in the UK and a growing number of European countries. This development has occurred despite a clear lack of consensus on gang definitions: on the street, in policy and practice, and amongst academics. We have demonstrated the need to 
develop a stronger evidence base around gangs across Europe. Indeed, US gang researchers continue to question the usefulness and credibility of gang policies:

They range from social services for individual youth to special anti-gang legislation to crack down on and incarcerate gang members at greater levels than non-gang offenders. In between are street worker programs, organizational change, community empowerment and police suppression programs. ... Perhaps the most striking comment, however, is the almost complete lack of scientifically acceptable evidence for the success of any one of them, and the enormous complexity of attempting to implement a comprehensive approach involving a wide range of these approaches (Klein 2001: 9)

The increasing momentum around European gangs is taking place amongst an ever changing, particularly fractious, protectionist European backdrop. Political parties of all persuasions are focusing significantly on the control of immigration, with clear potential for gangs to be deployed as a 'useful enemy' elsewhere. We know that current European policy measures such as gang databases have the potential to focus disproportionately on young people from BAME backgrounds and there is an increasing tendency for the actions of certain groups of young people, for example, young European Muslims to be misappropriated as potential terrorist threats. Moreover, as the 'other' is perceived as a figure that threatens to unleash disorder, governments may justify deploying extreme strategies of defence and securitisation (Seidman, 2013). Post-Brexit, there is the potential to see gang discourse and subsequent policy response to be used interchangeably with terrorist policies. We are therefore concerned that gang injunctions, gang databases - and, latterly in the UK, the use of joint enterprise (Williams and Clarke 2016) - has the potential to target young, disproportionately ethnic minority males from already-heavily-policed and socially excluded neighbourhoods. Our research suggests that younger adolescent males, who have a greater street presence and less ability to find alternative locations to socialise, will be the more likely targets, leading to further social exclusion, marginalization and invariably, criminalization. 
References

Alexander, C. E. (2008). Rethinking Gangs; Gangs, youth violence and public policy.

Aldridge, J., Medina, J. and Ralphs, R. (2008) Dangers and problems of doing 'gang' research in the UK. In F. van Gemert, D. Peterson and I-L. Lien (eds) Street Gangs, Migration and Ethnicity. Cullompton: Willan.

Bannister, J., Pickering, J., Batchelor, S., Burman, M., Kintrea, K., and McVie, S. (2010). Troublesome youth groups, gangs and knife carrying in Scotland. Edinburgh

Berelowitz, S., Firmin, C., Edwards, G., and Gulyurtlu, S. (2012). "I thought I was the only one. The only one in the world." The Office of the Children's Commissioner's inquiry into child sexual exploitation in gangs and groups: interim report. London: Children's Commission.

Bjerregarrd, B. (2003) 'Antigang legislation and its potential impact: The promises and pitfalls,' Criminal Justice Policy Review, 14. pp171-192.

Braga, A. (2015) Police gang units and effective gang violence reduction. In S. Decker and D. Pyrooz (eds) The Handbook of Gangs. Chichester: John Wiley.

Brotherton, D. (2007) Proceedings from the transnational street gang/organization seminar Crime Media Culture 3(3): 372-381.

Cameron, D. (2011) Full transcript: Speech on the fight-back after the riots, Witney, 15 August 2011 http://www.newstatesman.com/politics/2011/08/society-fight-workrights [last accessed 5th May, 2017]

Campbell, A. (1984) The Girls in the Gang. Oxford: Basil Blackwell.

Carlsson, Y. and Decker, S. (2005) 'Gang and youth violence prevention and intervention: contrasting the experience of the Scandinavian welfare state with the United States.' In Cervantes, F. and Marchand, S. (eds) France ITACA Report. 'Interaction of different subjects Towards A strategic Common Answer concerning juvenile gangs'. International Juvenile Justice Observatory. Accessible via: http://www.oijj.org/en/docs/informes

Clarke, R., Crossley, C. and Williams, P. (2012), 'Gang and Youth Violence in Manchester City: a partnership problem profile', unpublished report, Manchester City Violent Gangs Board. 
Cornils, K. and Greve,V. (2004) 'Denmark on the Road to Organised Crime' In Fijnaut, C., and Paoli, L. (eds) (2004) Organised Crime in Europe: Concepts, Patterns and Policies in the European Union and beyond. Dodrecht: Springer. pp 853-878.

Chaskin, R. (ed.) (2010) Youth Gangs and Community Intervention: Research, Practice, and Evidence. New York: Columbia University Press.

Cottrell-Boyce, J. (2013) Ending gang and youth violence: A critique. Youth Justice 13(3): 193-206.

Crime and Security Act 2010. Available at: www.legislation.gov.uk/ukpga/2010/17/contents [Accessed 5 May 2017].

Dawson, P. (2008) Monitoring data from the Tackling Gangs Action Programme Home Office http://webarchive.nationalarchives.gov.uk/20080804123613/http://crimereduction. homeoffice.gov.uk/testbed/violentstreet011a.pdf [accessed 5th May 2017]

Decker, S. and Weerman, F. (eds) (2005) European Street Gangs and Troublesome Youth Groups. Lanham, MD: Alta Mira. pp 259-286.

Decker, S. and Pyrooz, D. (2012) "Gangs, Terrorism, and Radicalization." Journal of Strategic Security 4, no. 4: 151-166.

Decker, S. and Pyrooz, D. (eds) (2015) The Handbook of Gangs. Chichester: John Wiley.

Esbensen, F.-A. and Maxson, C. (2012) Youth Gangs in International Perspective: Results from the Eurogang Program of Research. New York: Springer.

Fraser, A. and Atkinson, C. (2014) 'Making Up Gangs: Looping, Labelling and the New Politics of Intelligence-Led Policing'. Youth Justice 14(2): 154-170.

Fraser, A. (2015) Urban Legends: Gang Identity in the Post-industrial City. Oxford: Oxford University Press.

Fraser, A. and Hagedorn, J. (2016) Gangs and a Global Sociological Imagination. Theoretical Criminology. Online first, available at: http://journals.sagepub.com/doi/abs/10.1177/1362480616659129 [Accessed 16th June 2017]

Fraser, A. (2017, forthcoming) Gangs \& Crime: Critical Alternatives. London: Sage.

Goldson, B. (ed.) (2011) Youth in Crisis?: 'Gangs', territoriality and violence. Abingdon: Routledge. 
Goldson, B. (2014) Youth justice in a changing Europe: Crisis conditions and alternative visions. In M. Devlin et al. (eds) Perspectives on Youth, Vol. 1. Strasbourg: Council of Europe Publishing, pp. 39-52.

Hacking, I. (1999) The Social Construction of What? Harvard, M.A.: University of Harvard Press.

Hallsworth, S. and Brotherton, D. (2011) Urban disorder and gang: a critique and a warning. London: Runnymede Trust.

Hallsworth, S. (2013) The Gang and Beyond: Interpreting Violent Street Worlds. Basingstoke: Palgrave Macmillan.

Harding, S. (2012). Street Government: The role of the urban street gang in the London riots. In D. Briggs, D. (Ed.) The English Riots of 2011: A Summer of Discontent. London: Waterside Press.

Harding, S. (2014). The street casino: Survival in violent street gangs. Policy Press.

HM Government (2011) Ending Gang and Youth Violence: A Cross-Government Report including Further Evidence and Good Practice Case Studies. London: Home Office

House of Commons (2015) Home Affairs Committee: Gangs and youth crime. Thirteenth Report of Session 2014-15, Report, together with formal minutes, London: The Stationery Office Limited

ITACA (2013) 'Interaction of different subjects Towards A strategic Common Answer concerning juvenile gangs'. International Juvenile Justice Observatory. Accessible via: http://www.oiji.org/en/docs/informes

Leinfelt, F., and Rostami, A. (2012) The Stockholm gang model: PANTHER. Stockholm: Erlander $A B$

Jones, T. and Newburn, T. (2002) Policy Transfer and Criminal Justice: Exploring US Influence over British Crime Control Policy. Maidenhead: Open University Press.

Klein, M. W. (1995) The American Street Gang. Its nature, prevalence and control. New York: Oxford University Press.

Klein, M. W. (2001) 'Resolving the Eurogang Paradox'. In Klein, M., Kerner, H.-J., Maxson, C. and Weitekamp, E. (eds) (2001). The Eurogang paradox: Street gangs and youth groups in the U.S. and Europe. Dordrecht: Kluwer Academic Publishers. pp $21-40$.

Klein, M. (2011) Who can you believe? Complexities of international street gang research. International Criminal Justice Review 21(3): 197-207. 
Lindström, P. (2010) Kriminella grupperingar. Retrieved December, 2011. Available from: www.brandskyddsforeningen.se. in Leinfelt and Rostami, (eds.) (2012): The Stockholm Gang Model. PANTHER. Stockholm County Police.

Matos, R., Vieira, A., Almeida, T., Rodrigues, A. and Rodrigues, N. (2013) Portugal ITACA Report. 'Interaction of different subjects Towards A strategic Common Answer concerning juvenile gangs'. International Juvenile Justice Observatory. Accessible via: http://www.oiji.org/en/docs/informes

Maxson, C. L., K. M. Hennigan and D. C. Sloane (2005). "'It's getting crazy out there": can a civil gang injunction change a community?" Criminology and Public Policy 4: 577-606.

Maxson, C. and Klein, M. (2006) Street Gang Patterns and Policies. Oxford: Oxford University Press.

Medina, J., Ralphs, R., and Aldridge, J. (2012). Hidden Behind the Gunfire Young Women's Experiences of Gang-Related Violence. Violence against women, 18(6), 653-661.

Muncie, J. (2007) Youth justice and the governance of young people: Global, international, national and local contexts. In S.A. Venkatesh and R. Kassimir (eds) Youth, Globalization, and the Law. Stanford, CA: University of Stanford Press.

Padovani, A., Ciappi,S., Brutto, S. and Santagata, B. (2013) Italy ITACA Report. 'Interaction of different subjects Towards A strategic Common Answer concerning juvenile gangs'. International Juvenile Justice Observatory. Accessible via: http://www.oiji.org/en/docs/informes

Pitts, J. (2008) Reluctant Gangsters: The changing face of youth crime; Willan Publishing: Devon.

Pitts, J. (2014) Who dunnit? Gangs, joint enterprise, bad character and duress. Youth and Policy 113: 48-59.

Policing and Crime Act 2009. Available at: www.legislation.gov.uk/ukpga/2009/26/contents [Accessed 05 May 2017]

Pozo, A., Gallego, P., Castro, F. and Pérez, M. (2013) Spain ITACA Report. 'Interaction of different subjects Towards A strategic Common Answer concerning juvenile gangs'. International Juvenile Justice Observatory. Accessible via: http://www.oiji.org/en/docs/informes

Ralphs, R. and Smithson, H. (2015) European responses to gangs. In S. Decker and D. Pyrooz (eds) The Handbook of Gangs. Chichester: John Wiley. 
Rostami, A. (2016) Policing gangs and organized crime: Reflections on conceptual confusion and its consequences from two Swedish case studies. In C. Maxson and F.-A. Esbensen (eds) Gang Transitions and Transformations in an International Context. New York: Springer.

Sanchez-Jankowski, M. (1991) Islands in the Street: Gangs and American Urban Society; Berkeley, CA: University of Berkeley Press.

Seidman, S. (2013) 'Defilement and disgust: Theorizing the other', American Journal of Cultural Sociology, 1(1), pp. 3-25.

Sharp, C., Aldridge, J., and Medina, J. (2006). Delinquent youth groups and offending behaviour: findings from the 2004 Offending, Crime and Justice Survey (Vol. 14, No. 06). London: Home Office.

Shute, J., Aldridge, J., and Medina, J. (2012) 'Loading the policy blunderbuss.' Criminal Justice Matters, 87(1), pp 40-41.

Shute, J. and Medina, J. (2014) Hunting gruffalo: 'Gangs', unreason and the big bad coalition. Criminal Justice Matters 96(1): 26-27.

Simon, J. (2007) Governing through Crime: How the War on Crime Transformed American Democracy and Created a Culture of Fear. New York: Oxford University Press.

Smithson, H., Ralphs, R. and Williams, P. (2013) Used and abused: The problematic usage of gang terminology in the United Kingdom and its implications for ethnic minority youth. British Journal of Criminology 53(1): 113-128.

Smithson, H. and Ralphs, R. (2016) Youth in the UK: 99 Problems but the gang ain't one? Safer Communities, 15(1), pp.11-23.

Spergel, I. A. (1995). The youth gang problem: A community approach (pp. 145-281). New York: Oxford University Press.

Stewart, G. (1998). "Black Codes and broken windows: the legacy of racial hegemony in antigang civil injunctions." Yale Law Journal 107(7): 2249-2279.

Thrasher, F. (1927/1963) [1927], The gang: A study of 1,313 gangs in Chicago (2nd edn), Chicago, III: University of Chicago Press.

van Burik, A., Hoogeveen, C., de Jong, B., Vogelvang, B., Addink, A., and van der Steegevan, M. (2013) Evaluatie Aanpak Criminele jeugdgroepen. Ministry of Security and Justice. 
van Gemert, F. (2005) Youth groups and gangs in Amsterdam: A pretest of the Eurogang Expert Survey. In S. Decker and F. Weerman (eds) European Street Gangs and Troublesome Youth Groups. Oxford: AltaMira Press.

van Gemert, F., Peterson, D. and Lien, I.-L. (eds) (2008) Street Gangs, Migration and Ethnicity. Cullompton: Willan.

Wacquant, L.J.D. (2008) Urban Outcasts: A Comparative Sociology of Advanced Marginality. Cambridge: Polity Press

Webb, V. and Katz, C. (2003) 'Policing in an Era of Community Policing', in S.Decker (ed.) Policing Gangs and Youth Violence. Belmont. pp 17-49.

Williams, P. and Clarke, B. (2016) Dangerous Associations: Joint Enterprise, Gangs and Racism. London: Centre for Crime and Justice Studies.

Young, T., Fitzgerald, M., Hallsworth, S., and Joseph, I. (2007). Groups, gangs and weapons: A Report for the Youth Justice Board of England and Wales. 